\title{
Re-evaluation of Contacts between Cyprus and Crete from the Bronze Age to the EARly Iron Age
}

\author{
Katarzyna Zeman-Wiśniewska \\ iD http:/orcid.org/0000-0002-4515-2142 \\ Stefan Wyszyński University in Warsaw
}

\begin{abstract}
This article argues that it is possible to distinguish certain stages of development of the contact between Cyprus and Crete, from Early Bronze Age up to the LBA/EIA transition period. To thoroughly do that, areas in which the connections are most clearly expressed: written sources, pottery, copper trade and cult practice influences are discussed. Possible sea routes between two islands, direct and as a part of a major route between Aegean, Levant and Egypt are described. Discussed written sources include possible place-names connected with Cyprus/Alasia in linear scripts and usage of the so-called 'Cypro-Minoan' writing. Examples of pots and sherds both Cypriot found in Crete and Cretan found in Cyprus are examined and possible copper trade (including lead isotope analysis) is considered. Further, alleged Minoan cult practice influences are thoroughly discussed. Finally all the above are chronologically reviewed and a course of development of contacts between Crete and Cyprus is proposed.
\end{abstract}

Keywords: Cyprus, Crete, Minoan, Bronze Age, Early Iron Age, contacts.

\section{Introduction}

The development of Cypriot and Cretan societies in the Bronze Age (BA) and (to a lesser degree) Early Iron Age (EIA) has been a subject of many research endeavours, ${ }^{1}$ including diachronic perspectives and searches for interconnections. ${ }^{2}$ Both islands were cradles of cultures which still mesmerize and fascinate us today, and are important pieces of the Eastern Mediterranean puzzle. As the body of data grows with each field season there are still questions to be answered, and to do so, one needs to take a step back and look

${ }^{1}$ This paper includes research done as a part of author's PhD in the Trinity College Dublin, supervised by Dr Christine Morris, funded by the Irish Research Council. Author would also like to thank Dr Laerke Recht for many valuable comments and suggestions and Mariusz Wisniewski for help with illustrations.

${ }^{2}$ See especially: Cadogan - Iacovou - Kopaka - Whitley 2012; Laffineur - Greco 2005; Cline - HarrisCline 1998; Cline 1994. 
at the bigger picture. This article argues that it is possible to distinguish certain stages of development in the connections between Cyprus and Crete, from Early Bronze Age up to the LBA/EIA transition period. To thoroughly do that, areas in which the connections are most clearly expressed: written sources, pottery, copper trade and cult practice influences will be discussed.

\section{Island Archaeology}

Crete and Cyprus are islands, and this geographical factor shaped their history. Island archaeology is a distinct sub-field concerned with the subjects of insularity and connectivity. Scholars usually present either a bio-geographical approach focused on climate and ecological factors, or a social approach, exploring the development of spatially conditioned identity and process of isolation or interaction with an outside world. ${ }^{3}$ The surrounding sea might be seen as a barrier or a bridge between familiar and unknown. An islander's perspective includes a dual experience and physical framework of land and sea. ${ }^{4}$ Islands usually become prominent and flourish for two reasons: the presence of rare resources and/or a unique location, serving as stepping stone to the mainland or other islands. The latter is true for both Crete and Cyprus. However, interregional contacts may also lead to foreign domination and exploitation of local resources or geographical position. Knapp ${ }^{5}$ proposes insularity as a key concept in island archaeology to explain social and economic developments. Insularity can result from personal, historical or social contingency. It is the quality of being isolated as a result of living on islands, or of being somewhat detached in outlook and experience. Broodbank, ${ }^{6}$ on the other hand, proposes in place of isolation and connection rather independence and integration.

\section{Sea Routes}

The character of Cretan - Cypriot relations was conditioned by the geography. It is therefore important to first illustrate their place within the eastern Mediterranean sea routes. Air and sea currents, assuming that Bronze Age sailors made use of all the possibilities offered by nature, shaped the routes. The most convenient route led east from Crete, via Kassos, Karpathos and Rhodes islands, along the south coast of Anatolia ${ }^{7}$ (Fig. 1A). The lack of natural harbours in this part of Asia Minor might have inclined travellers to visit the north coast of Cyprus. From there, it was possible to continue the journey either straight to one of the Levantine cities (like Ugarit) or first via the west coast down to the southern Cypriot harbours (like Hala Sultan Tekke). In this case, Cyprus would be one

\footnotetext{
3 Knapp 2008, 16.

4 Knapp 2008, 16-17; Broodbank 2000, 28-29.

5 Knapp 2008, 18.

6 Broodbank 2000.

7 Guzowska 1998, 145-146.
} 


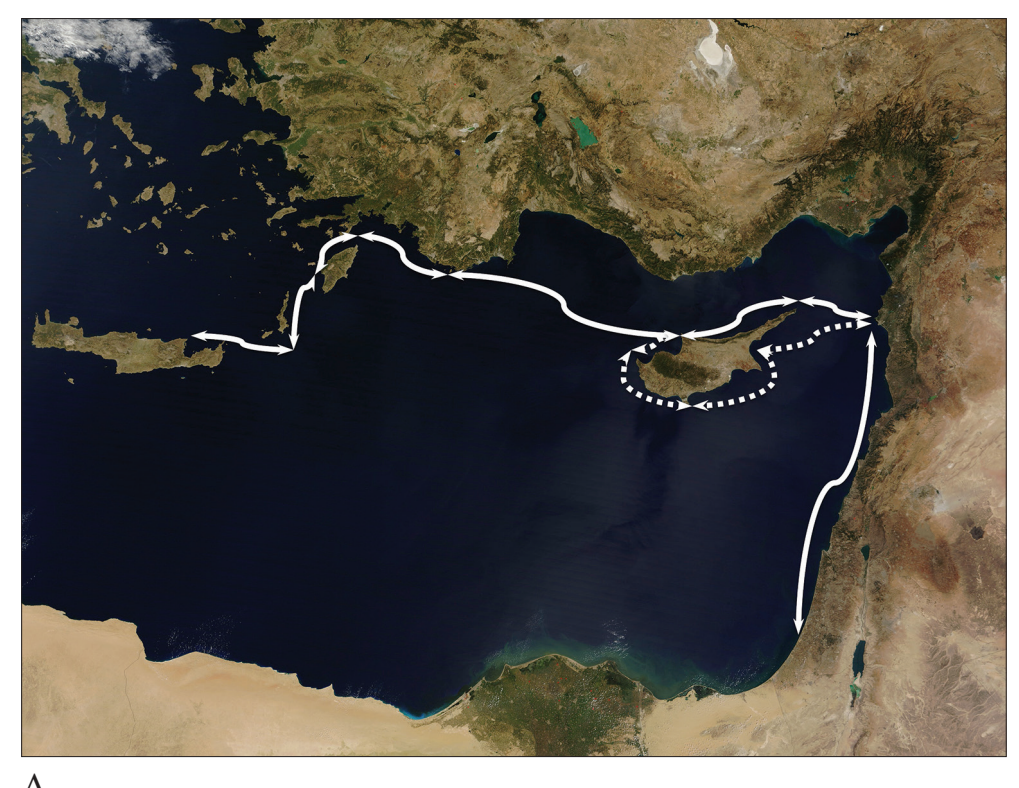

A

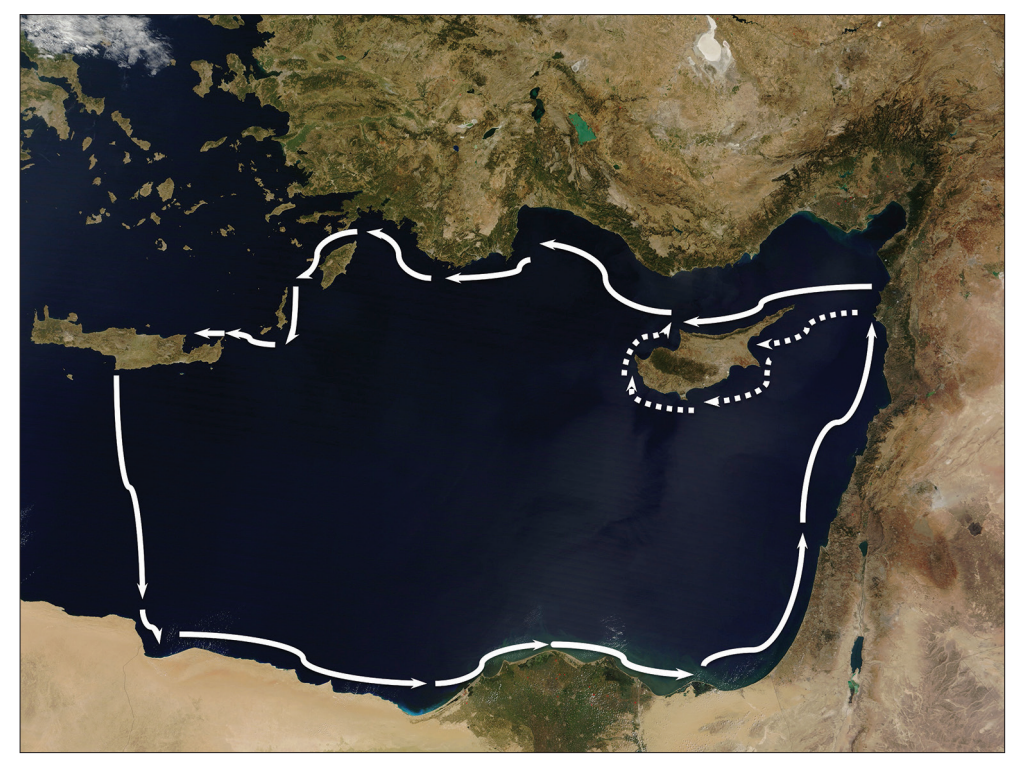

B 


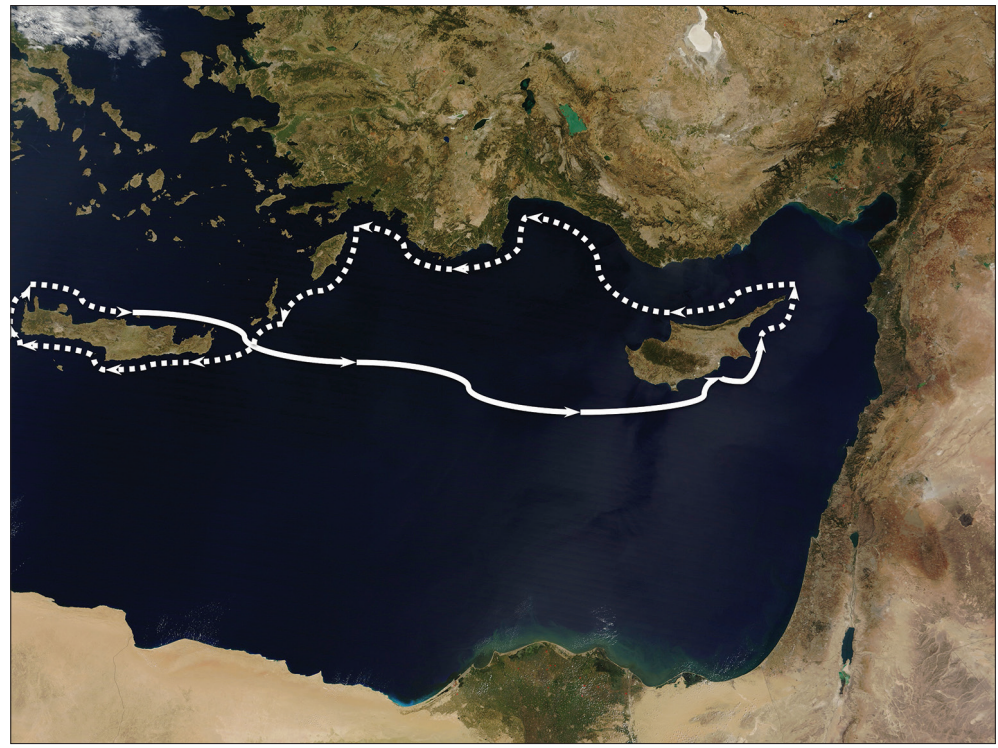

$\mathrm{C}$

Fig. 1. Possible sea routes between Crete and Cyprus (Maps made by M. Wiśniewski)

stop on a major route taken by the Minoans on the way to the Levant, or by Syrian ships going to the Aegean region.

The second possible route led south from Crete, via the Libyan coast, to Egypt (Fig. 1B). Then the ship could follow the Levantine coast and harbours, turn west to Cyprus and continue the journey passing by Anatolia, Rhodes, Karpathos and Kassos, back to Crete. This route could only be followed in one direction, and Cyprus would be on the way back from Egypt and the Levant. ${ }^{8}$

The third route could lead through the open waters directly between Crete and Cyprus (Fig. 1C). Then one would have to circle the island from south, east to the north coast, and passing Anatolia, Rhodes, Karpathos and Kassos, come back to Crete. This route could also only be followed in one direction, but could have started on either of the islands. ${ }^{9}$

All the described sea routes made the journey from Crete to Cyprus and vice versa possible, either directly or as an element of a longer journey connecting all the most important harbours of the eastern Mediterranean. The existence and usage of these sea routes is proved by Bronze Age shipwrecks found near the Anatolian coast, the holds of which contained objects from Egypt, the Levant, Cyprus and the Aegean. ${ }^{10}$ Many examples of anchors are also known, including two of Cypriot or Syrian type found in the main harbour town of southern Crete-Kommos. ${ }^{11}$

Bachhuber 2006, 347, 357-359.

Mantzourani - Theodorou 1989.

10 Pulak 2001, 13-60; Bass 1973, 29-38.

11 Shaw 1995, 279-291. 


\section{Written Sources for Cretan-Cypriot Relations}

Three scripts known from the Aegean: hieroglyphic, Linear A and Linear B. The first and second were used by the Minoans and remains undeciphered, but the third one was used by the Mycenaeans (and maybe Minoans) to record an archaic form of the Greek language. ${ }^{12}$ When the Linear B tablets were deciphered, it turned out that they provide an insight into the Mycenaean administrative system.

From Late Minoan III (LM III) Knossos, we have an archive of tablets written in the Linear B script; on one of these, the word 'a-ra-si-jo' occurs. Could this mean Alasia ${ }^{13}-$ Cyprus? It is equally possible to interpret it as a name or a description of a 'man from Alasia'. ${ }^{14}$ Similar questions are connected with the word 'ku-pi-ri-jo', comparable to the Greek name of Cyprus-Kvं $\pi \rho \circ$. It is not known whether it was used then as a place name; the word also occurs on tablets from Pylos. ${ }^{15}$ Next to the word 'ku-pi-ri-jo' is information about sheep, bronze, olive oil and coriander. ${ }^{16}$ It is possible then that a person of this name was responsible for flocks of sheep or metal production. ${ }^{17}$ However, the occurrence of olive oil with the words 'ku-pi-ri-jo' and 'a-ra-si-jo' might indicate trade with Cyprus in this product. Coriander (Coriandrum Sativum) is a plant known in the Mediterranean, used as a spice, natural preservative, added to bread and beer, or used in perfume production known even today under the name 'Chypre' ${ }^{18}$ There might have been trade in coriander between Crete and Cyprus, since seeds of this plant were found on the Bronze Age shipwreck of Uluburun. ${ }^{19}$

The undeciphered Cypriot script, called 'Cypro-Minoan' by Evans (and nowadays Cypriot syllabic), bears many similarities to the Aegean linear scripts. ${ }^{20}$ Similarities include shape of some signs used in both systems. The oldest tablets written in the Cypriot script are from Enkomi and are dated to the 16th/15th century BC, the period when Linear A was used on Crete. ${ }^{21}$ Comparisons with other Near Eastern systems of writing have not yielded any insights, and it is now established that the Cypriot script evolved from the Cretan Linear A.22 Later examples of the use of the script are known from the 13th/12th century BC, where the signs had already been simplified and adjusted to writing on clay tablets. At the beginning, the Cypriots probably wrote mostly on perish-

12 Chadwick 1987; Killen - Melena - Olivier 1987; Chadwick 1958.

13 The place name 'Alasia', identified with Cyprus or a part of it, occurs in texts from Alalakh, Crete, Egypt, Babylon, Byblos, Mari, Ugarit, and the Hittite kingdom. It was described as a land (or sometimes as a city) rich in copper, lying 'beyond the sea', and its king had high status within the eastern Mediterranean. Results of petrographic and chemical analyses of clay tablets sent from Alasia to Egypt and Ugarit (tablets EA33-34, EA37-38 and RSL.1) indicated that the clay was from the south-east region of Cyprus, see Goren - Finkelstein - Na'aman 2002.

14 Hellbing 1979, 57.

15 Bubenik 1974, 245.

16 Hadjisavas 2003, 101.

17 Bubenik 1974, 245; Hellbing 1979, 57.

18 Podbielski 1989, 162.

19 Bass 1998, 184.

20 Evans 1909, 69.

21 Masson 1979.

22 Powell 2002, 240. 
able materials like papyrus, since this was probably popular in the Aegean; wax plates were also used, fragments of which have been found in Kition and Hala Sultan Tekke. ${ }^{23}$ Later, possibly under the influence of contacts with the Near East, signs were adjusted to writing on clay tablets, which also meant a change in the information storing system. ${ }^{24}$ The Cypriots wrote on clay tablets, as was popular in the Near East, but also on clay balls, cylinders, terracotta vessels, metal objects and seals. Examples of Cypriot writing mostly come from Enkomi, but individual examples have also been found at other sites (e.g. Kalavassos-Ayios Dimitios, Paleapaphos). ${ }^{25}$ The only examples of the script found outside Cyprus are numerous 'potmarks' found on vessels (Fig. 2), and a list of names discovered in Ugarit. ${ }^{26}$ From the beginning of the Iron Age, a very similar, so-called 'Cypriot-classical' script was in use to write in the Greek language, and some signs from Linear B appeared in it. ${ }^{27}$ This script can be read today because of inscriptions from the Hellenistic period, which were written bilingually - the same text in Cypriot signs and the Greek alphabet. The language in which the earlier 'Cypro-Minoan' was written remains unknown. ${ }^{28}$

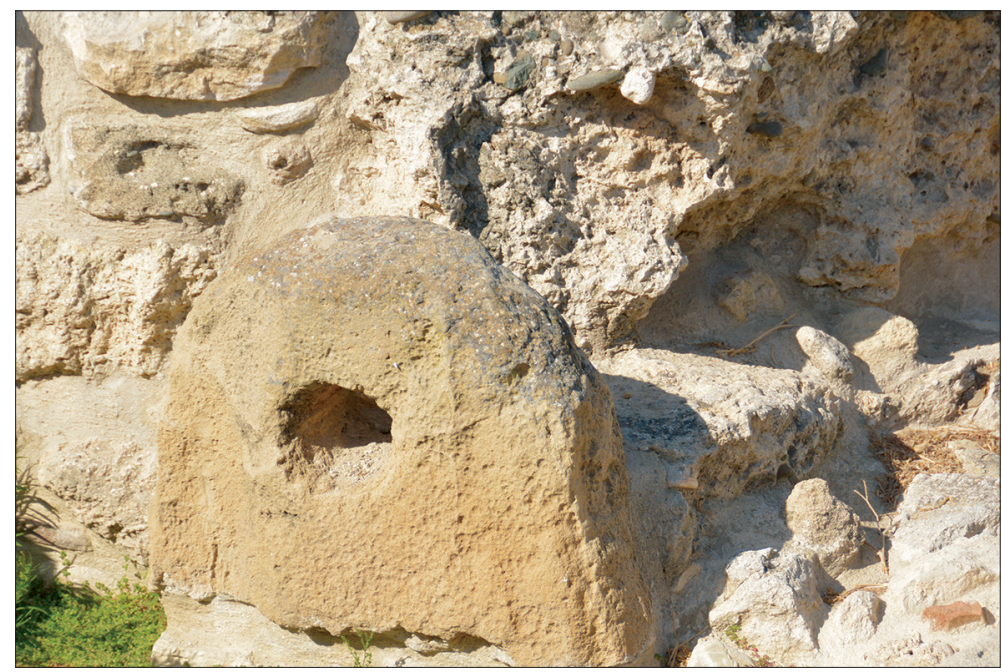

Fig. 2. Late Bronze Age anchor of Syrian type, temple in Kition (Photo by K. Zeman-Wiśniewska)

\section{Pottery}

The oldest example of Cypriot pottery found on Crete is an amphora fragment of Red Polished III ware found in Knossos. ${ }^{29}$ It is dated to Early Cypriot IIIB / Middle Cypriot

\footnotetext{
23 Smith 2002, 8-9.

24 Smith 2002, 10.

25 Smith 2002, 10, 20-21.

26 Tatton-Brown 1997, 80.

27 Tatton-Brown 1997, 81; Chadwick 1979.

28 Tatton-Brown 1997, 81; Masson 1979, 134.

29 Catling-McGillivray 1989.
} 
I (EC IIIB/MC I), and the context within which it was found was Middle Minoan I/IIA (MM I/IIA). ${ }^{30}$ An EC III bowl with incised decoration was discovered in a Subminoan grave in Phatsi, but it probably originally came from an earlier (EM-MM) settlement in Papadiokambos. ${ }^{31}$ In Poros-Katsamba, probably the harbour of Knossos, several cup fragments were found, dated to LC II. These were not in a magazine or the harbour area, but in a LM III grave..$^{32}$ From the Malia palace, the only example of a Red-on-Black bowl (MC III) is known, from a context dated to the LM III-LM IB period. ${ }^{33}$ Several fragments of Cypriot vessels have also been found in Gournia (LM IB), Pseira (LM IB and LM IIIA2-B) and Kato Zakros (LM IA). ${ }^{34}$ The only site that has yielded a larger assemblage of Cypriot pottery is the harbour town of Kommos in south Crete. It demonstrates intense contacts with Cyprus from at least LM IB until LM IIIA2 (MC-LC II). A Cypriot vessel fragment was also the oldest import found on the site. ${ }^{35}$ In MM IB-IIB, Cypriot pottery fragments appear in buildings connected with administration and storing, together with Levantine pottery. ${ }^{36}$ From MM IIB to LM III, Cypriot pottery can be found in all areas of Kommos, mostly in the form of bowls, jugs and pithoi. ${ }^{37}$ In LM IIIA/B Chania, several White Slip II bowls were also found. ${ }^{38}$ The popularity of Cypriot bowls is proven by several imitations of their characteristic wishbone handles attached to cups found in Trianda in Rodhos, Poros-Katsamba, Kommos, Pseira and Chania from LM IB through to LM II-IIIA. ${ }^{39}$

In Cyprus, the oldest example of Cretan pottery is a MM IA bridge spouted jar found in a grave in Lapithos Vrysi tou Barba from the EC III period. ${ }^{40}$ In another mortuary context, a MM IA Kamares cup was found, in Karmi-Palealona, in the so-called 'Sailors Tomb' ${ }^{41}$ A Kamares sherd was also found in Kourion (Site D, Tomb 101). ${ }^{42}$ From the harbour town of Tomba tou Skourou by the Ovghos river, many examples of pottery from Syria, Palestine, and Aegean are known, including LM IA-LM IIIB Crete. ${ }^{43}$ Two 'Minoan' cups have been found at the nearby cemetery of Ayia Irini, but Kanta suggests they might have been produced in Mainland Greece and that their decoration was only inspired by the Cretan style. ${ }^{44}$ A LM IA cup was also found in a well in PaleapaphoEvreti, and at Paleapaphos itself fragments of several LM IIIB stirrup jars have been found. ${ }^{45}$ From Kourion-Bamboula and Limassol-Kapsalos come fragments of LM IB

30 Warren - Hankey 1989, 115; Cadogan 1972, 5.

31 Graziado 2013; Graziado 2005, 328; Tsipopoulou 1997, 48.

32 Graziado 2005, 328.

33 Åström 1965, 79.

34 Betancourt 2004, 25; Betancourt - Davaras 1988, 207-205; Cadogan 1972, 5-9; Boyd-Hawes et al. $1908,42$.

35 Shaw 2004, 43.

36 Shaw 1998, 14.

7 Shaw 2004, 44.

8 Cadogan 1972, 6.

Graziado 2005, 331-332; Graziado 1999, 365-377.

40 Grace 1940, 24-25.

41 Keswani 2005, 378; Knapp 2013, 310.

42 Sørensen 2008, 171, no. 3.

43 Vermeule 1976, 78; Vermeule 1974, 2.

44 Kanta 2001, 24; Pecorella 1977, 21.

45 Maier 1975, 51, 71. 


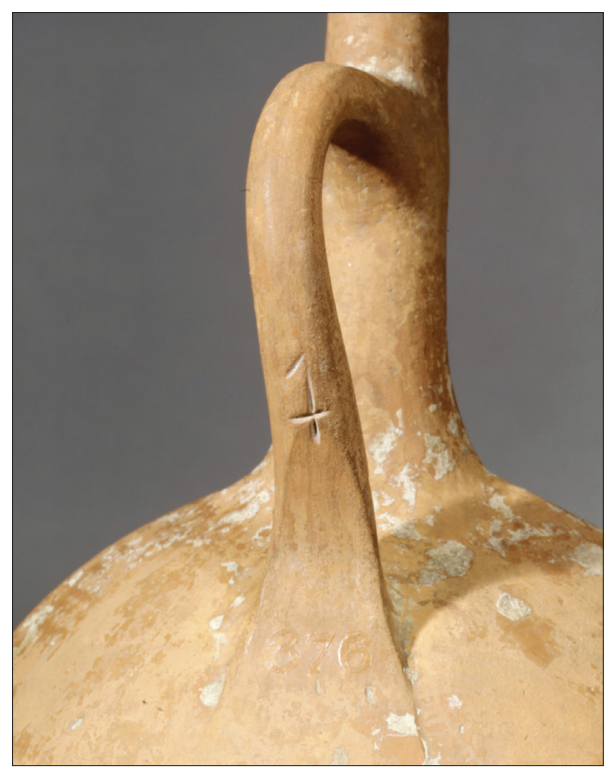

Fig. 3. Terracotta lentoid flask with a Cypro-Minoan sign (Metropolitan Museum of Arts New York, no. 74.51 .1312$)$

cups. ${ }^{46}$ Hala Sultan Tekke has yielded numerous examples of the Cretan pottery, including one LM I, two LM II, two LM IIIA and twenty four fragmentary and complete vessels of LM IIIB date, mostly stirrup jars from the Chania region. ${ }^{47}$ There were also fragments dated to the LM IIIC period, and some local imitations of Minoan pottery of LM IIIB-C date. ${ }^{48}$ In recent years new excavations in Hala Sultan Tekke yielded even more imports from Crete dated to LM III periods, ${ }^{49}$ including a complete Late Minoan II/ IIIA piriform jar with bird motifs (Fig. 3). ${ }^{50}$ Fragments of LM III kraters and stirrup jars are also known from Pyla-Kokkinokremos, the kraters probably imported from Palaikastro. ${ }^{51}$ There are also several LM III kraters and stirrup jars dated to LM III from Enkomi (from LC IIA/B-IIIC contexts). ${ }^{52}$ Individual fragments of LM IIIA-C pottery, mostly Chania transport stirrup jars, were found in Maroni, Kition, Pyla-Verghi, Sinda, Korovia-Nitovikla, Athienou, Dhenia-Kafkalla, Kalopsidha-Ayios Iakovos and KaimakliEvretadhes. ${ }^{53}$

46 Nikolaou 1980-1981, 56; Karageorghis 1978, 888-889; Benson 1972, 106.

47 Karageorghis 1990, 16; Åström 1980, 40.

48 Kanta 2001, 32; Åström 1986, 64.

49 Dr Laerke Recht personal communication.

50 Fischer - Bürge 2018, 54, fig. 20.

51 Catling - Karageorghis 1961, 116-117.

52 Catling - Karageorghis 1961, 113-114, 119.

53 Catling - Karageorghis 1961, 113; Karageorghis 1990, 19; Guzowska 1998, 143. 


\section{Cypriot Copper}

Copper is a basic component of bronze (80-90\%); the second is tin. It was used to produce tools, weapons, figurines, big statues and everyday objects. Copper was an important part of Bronze Age trade (and/or exchange systems), as is also illustrated in the written records concerning Alasia ${ }^{54}$ - usually identified as Cyprus. The first Cypriot examples of objects made of copper date to the Chalcolithic period, from the settlement of Mosphilia. ${ }^{55}$ The development of bronze production techniques came with settlers and influences from Anatolia at the beginning of the Bronze Age. ${ }^{56}$ At first, copper was probably imported along with bronze objects from Anatolia, the Levant and the Aegean. ${ }^{57}$ These include Minoan daggers found in several EC III-MC I graves in north Cyprus, although their origins remain controversial and they might be not from Crete but Ugarit or Byblos. ${ }^{58}$ From the $\mathrm{MC}$ period onwards, there was an intensification in copper mining in the Troodos mountains, for example at the sites of Ambelikou and Apliki-Karamallos. ${ }^{59}$ Copper was exported in the form of so-called oxhide ingots (Fig. 4), to facilitate transport - it could be carried on a shoulder held by one or two corners (Fig. 5), and had a standardized weight of $29 \mathrm{~kg} .{ }^{60}$ Some of the ingots were marked with signs from the Cypriot syllabic script. ${ }^{61}$ However, the only known cast of this shape was found in Syria at Ras Ibn Hani, although the traces of copper in it were of Cypriot origin..$^{62}$ How important metallurgy was for the Cypriot society is illustrated by its connection with cult, in the form of workshops near the temples, or the bronze figurines known as the Ingot God and Astarte-on-the-ingot, depicting a male and a female standing on miniature oxhide ingots. ${ }^{63}$

Sources of metals found on Crete are established using the isotope method, which allows us to see the complexity of copper import during the Bronze Age, when Cyprus clearly was not the only option. In the EM period, Ayia Photia Cycladic copper was in use: at Chrysokamino, it was imported from the island of Kythnos, and the objects found in the Mesara tombs were produced using metals from Kythnos, Lavrion, local Cretan resources (which were very scarce) and Cyprus. ${ }^{64}$ For the MM II palace in Malia, copper was imported from Anatolia and Cyprus, while other bronze objects dated to MM II-III point to Attica (Lavrion) ${ }^{65}$ For objects dated to LM II-LM IIIB from Knossos, Samonas, Armenoi and Pighi, the main source of copper was also Mainland Greece; only a few examples were made with Cypriot copper. ${ }^{66}$ Only two oxhide ingots found at Kommos

\footnotetext{
4 Alasia was a source of cooper for Egyptians, Hittites and Babylonians: Hellbing 1979, 42, 53-57.

Steel 2004, 114-115.

Webb - Frankel 1999, 31-33.

7 Gale - Stos-Gale 2006.

58 Catling - Karageorghis 1961, 110-112; Braningan 1966, 123-126.

59 Muhly 1979, 88; Catling 1986, 93.

60 Muhly 1979, 95; Stos-Gale et al. 1997, 84.

61 Muhly 1979, 89.

62 Legarce - Bounni - Saliby 1983, 277-290.

63 Knapp 1986, 2-3, 9-12; Webb 1999, 69-82.

64 Gale 1990, 299-316; Watrous 2001, 216.

65 Stos-Gale - Macdonald 1991, 267; Poursat - Loubet 2005, 120.

66 Stos-Gale - Gale 1990: fig. 15; Muhly 1986, 53.
} 


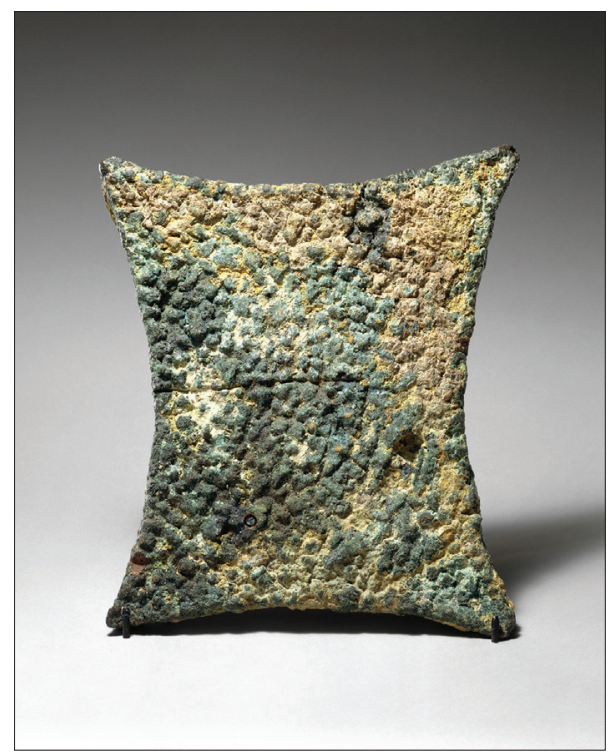

Fig. 4. Cypriot Late Bronze Age copper ingot $(35.5 \mathrm{~cm} \times 44.5 \mathrm{~cm}, 28.6 \mathrm{~kg}$ ) (Metropolitan Museum of Arts New York, no. 11.140.7)

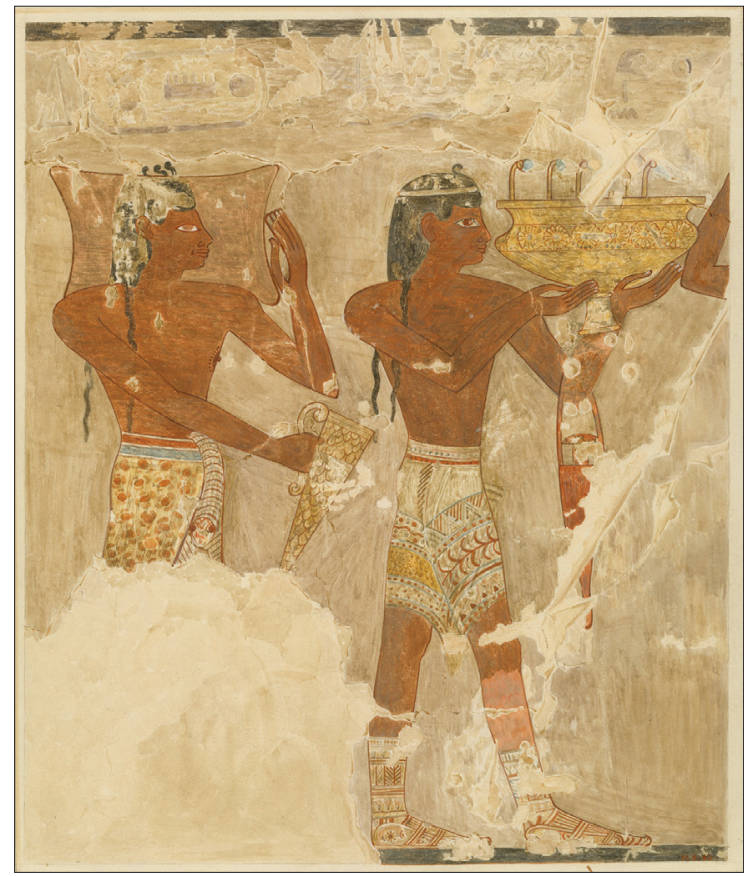

Fig. 5. Keftiu with an ingot, detail from a scene depicting foreigners bringing gifts in the tomb of Rekhmire (TT 100) at Thebes, drawing by Nina de Garis Davies (Metropolitan Museum of Arts New York, no. 31.6.42) 
were of Cypriot origin, others_-from Ayia Triada, Kato Zakros, Gournia, Tylissos, Kato Syme, Mochlos, Palaikastro and Knossos - were mostly from Attica or even Sardinia. ${ }^{67}$ On frescoes in Egyptian tombs from the times of Hatshepsut (Tomb of Senenmut), Thutmosis III (Tombs of Puimre', Menkheperra'sonba, Amenusera, Amenemhaba and Rekhmire; Fig. 5) and Amenophis III (Tombs of Kenamun and 'Anena), a people called 'Keftiu', identified as from Crete, carry oxhide ingots. ${ }^{68}$ In the light of isotope tests, it is possible that Minoans exported Lavrion copper to Egypt, rather than acting as a middleman for the Cypriots.

\section{Transition to the Iron Age (LM IIIC-SM I/LC IIIA-B)}

The period of LM IIIC to SM I in Crete corresponds to LC IIIA-B in Cyprus. An extensive review of Cretan external relations in the EIA, including those with Cyprus, is presented by Jones in his monograph on this subject, and what follows below is mostly a summary of his work. ${ }^{69}$ From 11 th century BC Kition, floor II, various Subminoan elements appearing in Proto-White painted ware are attested. ${ }^{70}$ An amphoroid krater found in Alassa might have been inspired by a Subminoan vessel, and this may also be the case with a few examples of Proto-white Painted pyxides known from Cyprus. ${ }^{71}$ There are some general similarities between the islands' techniques of ceramic fabrication, pottery shapes and decoration, observed by Yon $^{72}$ and Desborough ${ }^{73}$. These include the often discussed agrimi/goat motif in Cyprus, which Yon believes to have a Syrian origin $^{74}$; Iacovou ${ }^{75}$ suggests it could be an example of Cypriot influence on the Cretan repertoire, and not vice versa, as argued by Desborough. ${ }^{76}$ Desborough $^{77}$ also points out a shape of bird vase common in this century found on sites on both islands, especially Type II, which might have been brought from Crete to Cyprus or vice versa. In Crete, clay stands from Karphi might have been inspired by bronze examples from Cyprus, and flasks from Vrokastro could also be considered imitations of Cypriot pots. ${ }^{78}$ There is a small amount of Subminoan sherds found on Cyprus. At Enkomi, one Cretan vase was found ${ }^{79}$ and from Salamis, a three-legged coarse ware cooking pot and an incised pitcher are known. ${ }^{80}$ All Cypriot artefacts found on Crete are of metal: iron spits and a bronze

67 Rehak - Younger 2001, 415-416; Gale - Stos-Gale 1988, 349-384; Gale - Stos-Gale 1986, 81-100; Muhly 1979, 93; Cadogan 1972, 9.

68 Muhly 1979, 89-90.

69 Jones 2000, 213-239, 293-343.

70 Karageorghis 1968, 182-183; Karageorghis 1976, 90.

71 Karageorghis 1975, 48.

72 Yon 1979, 245.

73 Desborough 1972b, 57.

74 Yon 1970, 315-316.

75 Iacovou 1988, 35-36.

76 Desbourough 1972b, 57.

77 Desbourough 1972a, 275.

78 Desborough 1972b, 118-119.

79 Dikaios 1969, 316-317, Pl. 95.26; Betancourt 1985, 186.

80 Yon 1971, 28-29, no. 55; Yon 1979, 242. 
tripod stand from Knossos Fortesa, an iron knife and a bronze tripod from Vrokastro, a bronze bowl and tripod base from Eleutherna, a bronze pendant from Karphi, and two arched fibulae from Phaistos. ${ }^{81}$

Many scholars are inclined to see a population movement from Crete to Cyprus in the 11th century BC, due to LM IIIC disturbances. 'Goddesses with Upraised Arms' figurines are usually used as one of the main arguments. Desborough ${ }^{82}$ argues for a movement of population based on the similarities in styles and shapes of pottery, and particularly Type II bird vase occurrences, as presented above. He also suggests that without Cretan refugees in Cyprus, contacts between these islands would shrink visibly in the EAI period. Karageorghis ${ }^{83}$ has observed similarities between terracotta centaurs/sphinxes from Aghia Triada (Crete) and Enkomi (Cyprus), and describes Cypriot clay models of sanctuaries as a Subminoan element. Further, Yon ${ }^{84}$ sees the Cypriot material as an illustration of a movement of religious expression from Crete to Cyprus, but in the other direction she observes only a presence of isolated travellers or merchants. Conversely, Nikolaou ${ }^{85}$ argues that, besides the occurrence of 'Goddesses with Upraised Arms' (discussed below), there is not enough evidence to suggest a population movementespecially points out the lack of Cretan cooking ware on Cyprus.

\section{Minoan Cult Symbols in Cyprus}

As D'Agata points out, differences between the nature of cult and socio-economic structures in Crete and Cyprus are so clear that "there are no bases to support the idea of an interaction between the two islands in pure terms of cult activity or cult performed" ${ }^{86}$ The important Minoan symbol of the double axe is known only as a motif on two imported cups from the Ayia Irini LC IA2-IB cemetery, another one from the Kolokassides Collection and two fragmentary kraters from Enkomi and Hala Sultan Tekke. ${ }^{87}$ Only one, fragmentary Minoan figurine has been found so far, in a tomb in Hala Sultan Tekke, alongside Mycenaean-imported wares. ${ }^{88}$ However, there are some elements connected with cult that are often cited as a sign of a direct influence from Crete to Cyprus, including 'horns of consecration', wheelmade terracotta bulls, and so-called Goddesses with Upraised Arms (GWUAs) figurines. As there are different interpretations of their role and meaning, it is of interest to briefly discuss them. 'Horns of consecration' were stylised bovine horns, known either as free standing or an element of altars or architecture. The stone, middle or large size 'horns of consecration' were an important element of the Neopalatial cult and power ideology on Crete, and were associated with columned struc-

81 Jones 2000, 144.

82 Desborough 1972a, 275; Desborough 1972b, 57.

83 Karageorghis 1976, 9.

84 Yon 1979, 245.

85 Nikolaou 1979, 255.

86 D'Agata 2005, 3.

87 Papadopoulos - Kontroli-Papadopoulos 1992, 330.

88 HST season 2019, http://www.fischerarchaeology.se/?page_id=2797 (accessed: 1 May 2020). 
tures ${ }^{89}$ Later, in the LM IIIA-C they became smaller, made of clay or painted on vessels, and they became one of the attributes of GWUA figures ${ }^{90}$ (below). In this period (LH IIIA-B), stone horns were in use in Mainland Greece, as attested by examples from Mycenae, Gla and Pylos. ${ }^{91}$ Horns of consecration were also found in Cyprus and they were studied by Loulloupis ${ }^{92}$ divided in to two chronological groups: LBA examples from Kition, Myrtou-Pighdes, Enkomi, Pyla-Kokkinokremos and Kourion, and those dated to the EIA from Meniko, Khapotami, Haghia Moni, Kouklia (Paleapaphos), Kition and Salamis. However, 'horns of consecration' were a well-known and popular symbol in Levantine beliefs and cult practice at least from the 10th century BC, and much earlier in Anatolia, first as a part of incense altars and later also larger altars associated with blood sacrifice. ${ }^{93}$ The Cypriot ones, as observed by Hitchcock ${ }^{94}$ resemble rather the Levantine examples both in form (blunted tips) and usage, as they are associated with altars rather than with important entryways; there were also some regional diversities in the way they were executed. Another possibility is that different regions of Cyprus adapted the 'horns of consecration' differently due to contacts with either the Levant or the Aegean and local traditions (presence of bovine figurines). Thus, there can be no certainty that this religious symbol should be cited as a sign of Aegean influences and even less so as a sign of a direct Cretan involvement in the development of Cypriot religious practice.

The presence of cattle in Cypriot cult is very visible in a variety of forms, including the aforementioned 'horns of consecration', but also as skulls, or the motif of bucranium on clay models of sanctuaries, pottery, stone and metal vases and jewellery. Bovine skulls were found in two main 'temples' at Enkomi (connected with the so-called Ingot God and Horned God), also metal figurines wearing horned helmets were found (resembling Near Eastern imagery) ${ }^{95}$ Large clay wheelmade bovine figures with painted decoration are known from both islands. Cretan wheelmade animal figures were characterised by a thick layer of clay that covers wheelmade, hollow cylinders that form a basic skeleton of the figures, they were distributed in open air sanctuaries, mostly in central Crete. ${ }^{96}$ Similar examples from Mainland Greece and from the Cyclades lack the thick layer of clay (which allows for a more naturalistic look) and have a more schematic appearance. ${ }^{97}$ Large wheelmade bovine figures were present in Cyprus in the LC IIIA period and are known from Enkomi and several other sites. Only the ones from Enkomi were found in a securely dated context, and their production continued to the Archaic period ${ }^{98}$ As D'Agata observes, Cypriot wheelmade bulls might be influenced by the Mycenaean and Cycladic art rather than Cretan. ${ }^{99}$ However, might be true for the earliest examples, dated to the LC III, which are stylized and have a linear decoration it is less obvious at the end

89 D’Agata 2005, 4.

90 D’Agata 2005, 4.

91 Hägg 1985.

92 Loulloupis 1973.

93 Hitchcock 2002, 233-249.

94 Hitchcock 2000, 98-101; Hitchcock 2002, 234, 237.

95 Papadopoulos - Kontroli-Papadopoulos 1992, 332.

96 D’Agata 1997, 88; D’Agata 1999, 43-44; D’Agata 2005, 5.

97 D'Agata 2005, 5.

98 Kourou 2002, 19.

99 D’Agata 2005, 5. 
of the LC III and in the Cypro-Geometric period. Later bull figures are of a larger size, $0.2-0.3 \mathrm{~m}$ long, and are more naturalistic in rendering and have male genitals, which is characteristic for the Minoan terracottas. Moreover, their painted decoration resembles the motifs from the Aegean pottery. However, some of the Cypro-Geometric figures include elements of the local traditions (like some of the examples from Ayia Irini). ${ }^{100}$

It has long been assumed that there is a direct link between the EIA Cypriot Upraised Arms (UA) figurines and the Cretan LBA figures known as Goddesses with Upraised Arms (GWUA). ${ }^{101}$ The Upraised Arms (UA) figurines are the most common anthropomorphic terracottas of this transitional period (in Cyprus), representing a standing person, most commonly female (ungendered and double-gender examples are also known ${ }^{102}$ ), wearing a long garment, with arms stretched upwards and often bent, sometimes wearing a polos (Fig. 6). Cretan GWUA figures and figurines characterize the social and religious life of the LM IIIB-C (Postpalatial) period. They were especially popular in the eastern part of the island in new settlements set in a mountainous region. ${ }^{103}$ The changes in the religious symbolism in the LM IIIB-C period, of which GWUAs are the most visible sign, were caused by a sense of insecurity and lack of authorities after the final fall of the palaces. ${ }^{104}$ Nevertheless, their origins lay in Bronze Age coroplastic traditions, and are strongly rooted in Minoan iconography. This creative continuity is also visible in the re-interpretation of some of the old symbols, like the horns of consecration, which became one of the GWUA attributes. ${ }^{105}$ Cypriot UA figurines are morphologically similar to Cretan terracottas. They also at first differ noticeably from their Bronze Age predecessors in the manner of representation, such as in the new characteristic gesture, replacing arms folded under the breasts or alongside the body, and in the long garment instead of nudity. These new terracottas were also made to stand by on their own and were therefore probably handled differently than the LBA ones. Further, Late Cypriot figurines were mostly found in mortuary contexts, while UA figurines were found within sanctuaries, and the meaning and function of figurines thus changed during the LBA/EIA transition period. Nevertheless, some signs of continuity in Cypriot coroplastics are also noticeable; the facial characteristics and painted decoration of the UA figurines resemble the LC terracotta style, and are, as in the Bronze Age, mostly female. UA figurines also have often diagonal lines, painted on the front and/or at the back of the torso of the figurine. This is an element known since the LBA, where it was depicted on a nude torso. The presence of jewellery is also a sign of continuity - painted bands on arms and neck, and pendants. However, the most distinct sign of continuity is the association of UA figurines with LBA Cypriot sanctuaries. Despite the changes in settlement patterns, many cult places continued longer than the habitation of sites (the best example being Enkomi). It is possible to observe that attachment to a place is often stronger than attachment to beliefs and/or cult practices. This might indicate that actually it was the descendant of the population that inhabited Cyprus already in the LBA

\footnotetext{
100 Kourou 2002, 19-20.

101 Karageorghis 1977; Karageorghis 2005.

102 Zeman-Wiśniewska 2012.

103 Gesell 2004, 2012, 2018.

104 Driessen 2001.

105 Gesell 2006.
} 


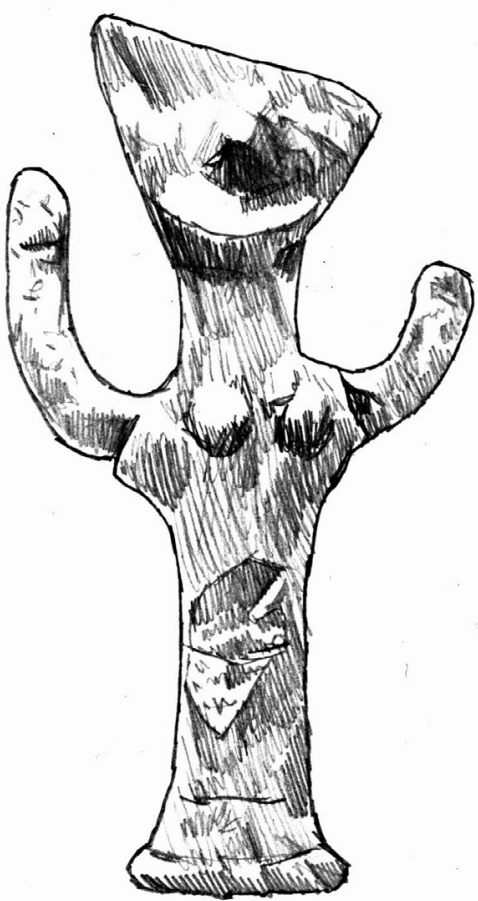

Fig. 6. Cypriot Upraised Arms figurine from Kition, 11th-10th century BC, $14.5 \mathrm{~cm}$ height (Drawing by P. Butler)

that produced and used UA terracottas. Along with the local traditions, the developing EIA religion was influenced by Mycenaean rather than by Minoan culture. The facial characteristics of Cypriot UA figurines bear a strong visual similarity to the Mycenaean figures. The cylindrical, stem-like lower part of the body and the polos, instead of the Cretan GWUAs' tiara, are indicators of influence from the Mycenaean coroplastic tradition. The emblematic gesture of raised but un-bent arms, and the simple indication of fingers in paint (or their absence) recall figures found in Greek sanctuaries, including phi, psi and tau figurines.

\section{Re-evaluation of Contacts between Crete and Cyprus}

Contacts between Crete and Cyprus started in the transition period between the Early and Middle Bronze Age. The first known Minoan imports in Cyprus, daggers dated to EM III-MM I, were found in graves dated to the EC III-MC I and as mentioned before remain controversial. ${ }^{106}$ Perhaps already in EM some amounts of Cypriot copper were imported to Crete, but the main source was the island of Kythnos. The oldest Minoan vessel found

106 Catling - Karageorghis 1961, 110-112; Braningan 1966, 123-126. 
in Cyprus is dated to the MM period, and fragments of Cypriot pottery found at Knossos and Phatsi in Crete are attributed to EC III and EC III/MC I. ${ }^{107}$ For the Minoan culture, this was the beginning of the First Palaces and in Cyprus the most developed was the north of the island. The transition from the Early to Middle Bronze Age for both islands was a moment of intensification of contacts with the Levant and Egypt and the presence of visible eastern influences in metallurgy. ${ }^{108}$ In this period, Cyprus was probably only a stop on the trade route with Near East and later Egypt for the Cretans. This is illustrated by the small assemblage and randomness of finds. It is also worth noting that Minoan imports mostly come from sites on the northern part of the island, a region convenient to visit by ships on the way from the Aegean to the Levant or vice versa. This was also the region where important Cypriot centres were developing.

In the Middle Bronze Age, a continuation of this pattern of contacts is visible, as part of wider east-west relations. In the MM IB-II period (Old Palace Period) in the main harbour of southern Crete-Kommos, among Levantine imports appear some Cypriot pottery. Its amount rises towards the end of the MM, and it is the most visible trace of contacts between the two islands in this period. In Mallia was found a Cypriot vessel (MM III) and some copper from Cyprus (MM II), however more important source of this metal was Lavrion. ${ }^{109}$ In Cyprus, only one Kamares cup (dated to MM IIA) has been found. ${ }^{110}$ At the time of the Amarna period of diplomatic correspondence in the Near East, a place called Alasia appears in the letters. Identified as Cyprus, this marks the island's presence within the eastern political and economic world. ${ }^{111}$

In Crete, the LM IA period was characterised by a rapid development of culture and art of the New Palaces and intensive overseas contacts. Imports from Cyprus have been found at Kato Zakros and Kommos. However, copper was imported from Attica and Anatolia, although some amount from the Cypriot sources appeared in a shape of oxhide ingots at Kommos. ${ }^{112}$ The end of the MC III and the beginning of the LC I (corresponding to LM IA) is a period of important changes in Cyprus. They are illustrated by the appearance of fortifications and fast expansion of centres on the southeast of the island. In this period, Minoan imports appear at Toumba tou Skourou located in the northwest, and for the first time in the south and east, at Hala Sultan Tekke and Paleapaphos. The changing spatial pattern of imports from Crete illustrates internal developments in Cyprus and overtaking of the international relations by new settlements (this is even better illustrated by Levantine imports). What is also of importance is that the first known examples of Cypro-Minoan writing appear in this, which clearly shows that there were contacts between the Minoan and developing Cypriot élites. ${ }^{113}$

The end of the LM IA period in Crete was marked by the Thera volcanic eruption, which also caused the collapse of the northern sea route, which had been crucial in the

107 Cadogan 1972, 5; Warren - Hankey 1989, 115.

108 Muhly 1979, 88.

109 Stos-Gale - Macdonald 1991, 267; Poursat - Loubet 2005, 120.

110 Keswani 2005, 378.

111 Vincitelli 1976, 41; Hellbing 1979, 52-57.

112 Muhly 1979, 93; Gale - Stos-Gale 1986, 81-100; Gale - Stos-Gale 1988, 349-384.

113 Powell 2002, 240; Smith 2002, 10, 20-21. 
provision of copper from Lavrion. ${ }^{114}$ The amount of bronze objects decline in comparison with previous periods, especially after the collapse of the New Palaces in the LM IB/II. However, at the same time, the use of the Cypriot copper in Crete appears to rise. ${ }^{115}$ It is possible that Cyprus, which had not earlier been an important source of metals for Crete and was more economically tied to the eastern Mediterranean, could not provide the amount of resources that were needed. Moreover, the reduction of Cretan political strength and following that the international importance, weakened the position of Minoans as trade partners for Cypriots.

Cypriot pottery has been found at Minoan sites dated to the LMI B, including Gournia, Kommos, Knossos and Pseira. This is also the period when first cups with handles imitating the characteristic Cypriot wishbone handles appear on the islands of Rhodes, Kythera, Kea, and Poros-Katsamba in Crete. From LM II, they are known at other Cretan settlements, for example Kamilari, Kommos, Knossos and Ayia Triada. ${ }^{116}$ However, Cypriot pottery from this period is known only from Kommos. At the same time in Cyprus, Minoan imports are known in small numbers only from Hala Sultan Tekke, Limassol Kapsalos and Kourion. ${ }^{117}$ This might indicate a development of relations in which Crete was the receiving part, although these contacts might have been closer than in previous periods and more direct. Simultaneously, Minoan contacts with the Levant and Egypt were being taken over and dominated by the Mycenaeans, which is visible in the amount of Mycenaean imports in the east.

The LM IIIA-B period, whose turning point was the collapse of the last palace at Knossos, is the most well represented in the archaeological record in terms of relations between Crete and Cyprus. ${ }^{118}$ Cypriot pottery has been found at Chania, Kommos, Pseira and Poros-Katsamba. Minoan pottery has been identified in the assemblages from Toumba tou Skourou, Paleopaphos, Hala Sultan Tekke, Pyla Kokkinokremos, Maroni, Kition, Enkomi, Kalavassos-Ayios Dhimitrios, Pyla Verghi, Sinda, Korovia Nitovikla, Athienou, Dhenia Kafkalla, Kalopsidha Ayios Iakovos and Kaimakli Evretadhes. ${ }^{119}$ Moreover, imitations of Cretan vessels have been found at Hala Sultan Tekke, Enkomi and Pyla-Kokkinokremos. ${ }^{120}$ At these sites, there is also a significant presence of Mycenaean imports. Crete clearly became a part of contacts between the Mycenaean culture and Cyprus. Cretans almost certainly took part in the population movement at the end of the Bronze Age, but probably hand in hand with the Mycenaeans. The site of Pyla-Kokkinokremos is usually cited as an example, where locally produced pottery was made in the LM III style in a significant quantity. ${ }^{121}$

The character of the EIA in Cyprus was defined already in LC IIIB, being marked by changes in settlement patterns and the growing presence of foreign influences, both from east and west, and instantly reinterpreted and incorporated into the local culture

114 Klontza-Jaklová 2016.

115 Muhly 1986, 53; Stos-Gale - Gale 1990, fig. 15.

116 Graziado 1999, 365-377; Graziado 2005, 331-332.

117 Benson 1972, 106; Karageorghis 1978, 888-889; Nikolaou 1980-1981, 56.

118 Jones 2000, 213-239, 293-343.

119 Catling - Karageorghis 1961, 113; Karageorghis 1990, 19; Guzowska 1998, 143.

120 Åström 1986, 64; Kanta 2001, 32.

121 Kanta 2001, 32. 
(Iacovou 1989: 54-57). For the transition period between LBA and EIA (LM IIIC to SM I in Crete / LC IIIA-B in Cyprus), a small amount of Cretan sherds has been found in Cyprus, and all Cypriot artefacts found in Crete are made of metal. Moreover, Cretan clay stands of this period might have been inspired by Cypriot bronze ones. It is difficult to trace a population movement in this period in the archaeological material. On the other hand, Cypriot metal products did reach Crete and inspired local production. Despite the earlier vision of Crete being the source of the original cultural ideas (i.e. GWUAs, horns of consecration in cult or agrimi motif on pots), at least from the BA/IA transition, it was Cyprus that flourished and developed rapidly and would be the source of high quality products and new ideas.

BIBLIOGRAPHY

Åström, P. (1965), Red on Black Ware, Opuscula: Annual of the Swedish Institutes at Athens and Rome 5/73: 59-88.

Åström, P. (1980), Minoan Features at Hala Sultan Tekke, in: Proceedings of the 4th International Cretalogical Congress, Iraklion, 29 August-3 September, 1976, Athens: 35-42.

Åström, P. (1986), Hala Sultan Tekke - An International Harbour Town of the Late Cypriot Bronze Age, Opuscula: Annual of the Swedish Institutes at Athens and Rome 16: 7-17.

Bachhuber, Ch. (2006), Aegean Interest on the Uluburun Ship, AJA 110: 345-363.

Bass, B. F. (1973), Cape Gelidonya and Bronze Age Maritime Trade, Alter Orient und Altes Testament 22: 29-38.

Bass, B. F. (1998), Sailing between the Aegean and the Orient in the Second Millennium B. C., in: E. H. Cline, D. Harris-Cline (eds.), The Aegean and the Orient in the Second Millennium, (Aegaeum 18), Liège-Austin: 183-191.

Benson, J. L. (1972), Bamboula at Kourion: The Necropolis and the Finds Excavated by J. F. Daniel, Philadelphia.

Betancourt, P. P. (1985), The History of Minoan Pottery, Princeton.

Betancourt, P. P. (2004), Pseira and Knossos: The Transformation of an East Cretan Seaport, in: L. P. Day, M. S. Mook, J. D. Muhly (eds.), Crete beyond the Palaces: Proceedings of the Crete 2000 Conference, Philadelphia: 21-28.

Betancourt, P. P., Davaras, C. (1988), Excavations at Pseira, 1985 and 1986, Hesperia 57: 207-225.

Boyd-Hawes, H. et al. (1908), Gournia Vasilike and Other Prehistoric Sites, Philadelphia.

Braningan, K. (1966), Byblite Daggers on Cyprus, AJA 70: 123-126.

Broodbank, C. (2000), An Island Archaeology of the Early Cyclades, Cambridge.

Bubenik, V. (1974), Evidence for Alasia in Linear B Text, Phoenix 28: 245-250.

Cadogan, G. (1972), Cypriot Objects in the Bronze Age Aegean and Their Importance, in: V. Karageorghis (ed.), Proceedings of the First International Cyprological Congress, Nicosia: 5-13.

Cadogan, G., Iacovou, M., Kopaka, K., Whitley, J. (eds.) (2012), Parallel Lives: Ancient Island Societies in Crete and Cyprus. Papers arising from the Conference in Nicosia organizaed by the British School at Athens, the University of Crete and the University of Cyprus, in November-December 2006, (British School at Athens Studies 20), London.

Catling, H. W. (1986), Cypriot Bronzework East or West, in: V. Karageorghis (ed.), Acts of the International Archaeological Symposium "Cyprus between the Orient and the Occident", Nicosia: 91-103. 
Catling, H. W., Karageorghis, V. (1961), Minoika in Cyprus, Annual of the British School at Athens 55: $108-127$.

Catling, H. W., McGillivray, J. A. (1989), An Early Cypriot III Vase from the Palace at Knossos, Annual of the British School at Athens 78: 1-8.

Chadwick, J. (1958), The Decipherment of Linear B, Cambridge.

Chadwick, J. (1979), The Minoan Origin of the Classical Cypriote Script, in: V. Karageorghis (ed.), Acts of the Internationale Archaeological Symposium "The Relations between Cyprus and Crete, ca. 2000-500 B. C.", Nicosia: 139-143.

Chadwick, J. (1987), Linear B and Related Scripts: Reading the Past, London.

Cline, E. H. (1994), Sailing the Wine-Dark Sea: International Trade and the Bronze Age Aegean, Oxford.

Cline, E. H., Harris-Cline, D. (eds.) (1998), The Aegean and the Orient in the Second Millennium, (Aegaeum 18), Liège-Austin.

D’Agata, A. L. (1997), The Shrines on the Piazzale dei Sacelli at Ayia Triadha: The LM IIIC and SM Material, in: J. Driessen, A. Farnoux (eds.), La Crète Mycénienne: Actes de la table ronde internationale organisée par l'École française d'Athènes, (BCH Suppl. 30), Athenes: 85-100.

D'Agata, A. L. (1999), Defining a Pattern of Continuity during the Dark Ages in Central Western Crete, Studi micenei ed egeo-anatolici 41: 181-218.

D'Agata, A. L. (2005), Cult Activity on Crete and Cyprus at the End of the Late Bronze Age and the Beginning of the Early Iron Age, in: V. Karageorghis, H. Matthäus, S. Rogge (eds.), Cyprus: Religion and Society from the Late Bronze Age to the End of the Archaic Period, Möhnesee-Wamel: 1-17.

Desborough, V. R. (1972a), Bird Vases, Cretica Chronica 24: 245-277.

Desborough, V. R. (1972b), The Greek Dark Ages, London.

Dikaios, P. (1969), Enkomi. Excavations 1948-1958, Mainz.

Driessen, J. (2001), Crisis Cults on Minoan Crete?, in: R. Laffineur, R. Hägg (eds.), Potnia: Deities and Religion in the Aegean Bronze Age, (Aegaeum 22), Gothenburg: 361-369.

Evans, A. (1909), Scripta Minoa, vol. 1, Oxford.

Fischer, P. M., Bürge, T. (2018), The New Swedish Cyprus Expedition 2017: Excavations at Hala Sultan Tekke (The Söderberg Expedition). Preliminary results. With contributions by M. Ausiayevich, B. Placiente Robedizo, V. Barrera Alarcón, L. Recht \& D. Kofel, Opuscula: Annual of the Swedish Institutes at Athens and Rome 2018: 29-79.

Gale, N. H. (1990), The Provenance of Metals for Early Bronze Age Crete - Local or Cycladic?, Pepragmena: $299-316$.

Gale, N. H., Stos-Gale, Z. (1986), Oxhide Cooper Ingots in Crete and Cyprus and the Bronze Age Metal Trade, Annual of the British School at Athens 81: 81-100.

Gale, N. H., Stos-Gale, Z. (1988), Recent Evidence for a Possible Bronze Age Metal Trade between Sardinia and the Aegean, in: E. R. French, K. A. Wardle (eds.), Problems in Greek Prehistory, Bristol: 349-384.

Gale, N. H., Stos-Gale, Z. (2006), The Origin of Metals from some MC-LC Sites on Cyprus, based on Artefacts in the Collection of the Medelhavsmuseet, Stockholm - Coals to Newcastle again?, paper presented in Medelhavsmuseet, 31 March 2006, Stockholm.

Gesell, G. C. (2004), From Knossos to Kavousi: The Popularization of the Minoan Palace Goddess, in: A. P. Chapin (ed.), Charis: Essays in Honor of Sara A. Immerwahr, (Hesperia Suppl. 33), Princeton: $131-150$.

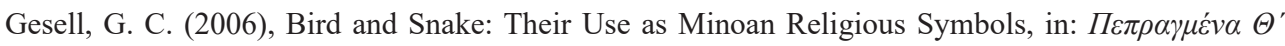

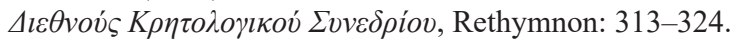

Gesell, G. C. (2012), The Kavousi Goddesses with Up-raised Hands: New Information on Technology, in: E. Mantzourani, P. P. Betancourt (eds.), Philistor: Studies in Honor of Costis Davaras, Philadelphia: 43-49. 
Gesell, G. C. (2018), The Goddesses with Up-raised Hands at Kavousi: The Relationship between Pot-

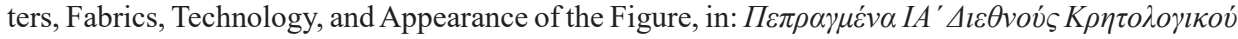

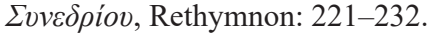

Goren, Y., Finkelstein, I., Na'aman, N. (2002), Petrographic Investigation of the Amarna Tablets, Near Eastern Archaeology 65: 196-205.

Grace, V. R. (1940), A Cypriote Tomb and Minoan Evidence for Its Date, AJA 44: 10-52.

Graziado, G. (1999), L'adorazione della wishbone handle nell'Egeo: un aspetto transcurato dei rapporti cipro-egei, in: V. La Rosa, D. Palermo, L. Vagnetti (eds.), Simposio Italiano di Studi Egei, Rome: 365-377.

Graziado, G. (2005), The Relations between the Aegean and Cyprus at the Beginning of Late Bronze Age: An Overview of the Archaeological Evidence, in: R. Laffineur, E. Greco (eds.), EMPORIA: Aegeans in the Central and Eastern Mediterranean, (Aegaeum 25), Liège-Austin: 323-332.

Graziado, G. (2013), A Middle Cypriot Unique Bowl from Eastern Crete and the Earliest Contacts

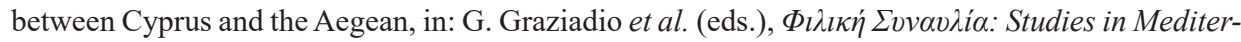
ranean Archaeology for Mario Benzi, Oxford: 165-175.

Guzowska, M. (1998), Geografia kontaktów morskich Krety i Cypru w II tysiącleciu p.n.e., in: W. Daszewski, H. Meyza (eds.), Cypr w badaniach polskich, Warszawa: 139-156.

Hadjisavas, S. (2003), Cyprus and Mediterranean World ca. 1600-600 B. C., in: N. C. Stampolidis (ed.), Sea Routes... from Sidon to Huelva, Interconections in the Mediterranean 16th-6th BC, Athens: 99-102.

Hägg, R. (1985), Die göttliche Epiphanie im minoischen Ritual, Athenische Mitteleilungen 101: 41-62.

Hellbing, L. (1979), Alasia Problems, Göteborg.

Hitchcock, L. (2000), Minoan Architecture: A Contextual Analysis, Jonsered.

Hitchcock, L. (2002), Levantine Horned Altars: An Aegean Perspective on the Transformation of Socio-Religious Reproduction, in: D. M. Gunn, P. M. McNutt (eds.), Imagining' Biblical Worlds: Studies in Spatial, Social and Historical Constructs in Honor of James W. Flanagan, London-New York: 233-249.

Iacovou, M. (1988), The Pictorial Pottery of Eleventh Century BC Cyprus, Göteborg.

Jones, D. W. (2000), External Relations of Early Iron Age Crete, 1100-600 B. C., Philadelphia.

Kanta, A. (2001), The Aegean World between East and West: Aspects of Common Cultural Elements from the 16th to the 11th c. B. C., in: N. C. Stampolidis (ed.), Sea Routes... from Sidon to Huelva, Interconnections in the Mediterranean 16th-6th BC, Athens: 20-40.

Karageorghis, J. (1977), La Grande Déesse de Chypre et son culte à travers l'iconographie, de l'époque néolithique au VI éme s. a. C., Lyon.

Karageorghis, J. (2005), Kypris: The Aphrodite of Cyprus Ancient Sources and Archaeological Evidence, Nicosia.

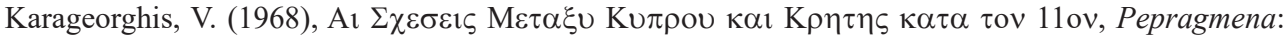
180-185.

Karageorghis, V. (1975), Alaas: A Protogeometric Necropolis in Cyprus, Nicosia.

Karageorghis, V. (1976), The Civilization of Prehistoric Cyprus, Athens.

Karageorghis, V. (1978), The Goddess with Uplifted Arms, Lundt.

Karageorghis, V. (1990), The End of the Late Bronze Age in Cyprus, Nicosia.

Keswani, P. (2005), Death, Prestige, and Copper in Bronze Age Cyprus, AJA 109: 341-401.

Killen, J. T., Melena, J. L., Olivier, J. P. (eds.) (1987), Studies in Mycenaean and Classical Greek Presented to John Chadwick, Salamanca.

Klontza-Jaklová, V. (2016), What's Wrong? Hard Science and Humanities-Tackling the Question of the Absolute Chronology of the Santorini Eruption, Brno.

Knapp, A. B. (1986), Cooper Production and Divine Protection: Archaeology, Ideology and Social Complexity on Bronze Age Cyprus, Göteborg.

Knapp, A. B. (2008), Prehistoric and Protohistoric Cyprus: Identity, Insularity, and Connectivity, Oxford. 
Knapp, A. B. (2013), The Archaeology of Cyprus: From Earliest Prehistory through the Bronze Age, Cambridge.

Kourou, N. (2002), Aegean and Cypriote Wheel-made Terracotta Figures of the Early Iron Age Continuity and Disjunction, in: E. A. Braun-Holzinger, H. Matthäus (eds.), Die nahöstlichen Kulturen und Griechenland an der Wende vom 2. zum 1. Jahrtausend v. Chr. Kontinuität und Wandel von Strukturen und Mechanismen kultureller Interktion, Möhnese: 11-34.

Laffineur, R., Greco, E. (eds.) (2005), EMPORIA: Aegeans in the Central and Eastern Mediterranean, (Aegaeum 25), Liège-Austin.

Legarce, J., Bounni, A., Saliby, N. (1983), Les fouilles à Ras Ibn Hani en Syrie (campagnes de 1980, 1981, et 1982), Paris.

Loulloupis, M. (1973), Mycenaean 'Horns of Consecration' in Cyprus, in: V. Karageorghis (ed.), Acts of the International Symposium: The Mycenaeans in the Eastern Mediterranean, Nicosia: 225-244.

Maier, F. G. (1975), The Temple of Aphrodite at Old Paphos, Report of the Department of Antiquities Cyprus: 69-80.

Mantzourani, E. K., Theodorou, A. J. (1989), An Attempt to Delineate the Sea-routes between Crete and Cyprus during the Bronze Age, in: V. Karageorghis (ed.), Proceedings of an International Symposium: "The Civilizations of the Aegean and Their Diffusion in Cyprus and the Eastern Mediterranean, 2000-600 B. C. ", Larnaca: 39-56.

Masson, E. (1979), L'apparition de l'écriture a Chypre: probable des contacts entre l'ile de Crete et l'ile de Chypre au cours de la premiere moitie du deuxieme millenaire, in: V. Karageorghis (ed.), Acts of the International Archaeological Symposium "The Relations between Cyprus and Crete, ca. 2000-500 B. C.", Nicosia: 134-138.

Muhly, J. D. (1979), Cypriot Cooper: Some Geological and Metallurgical Problems, in: V. Karageorghis (ed.), Acts of the International Archaeological Symposium "The Relations between Cyprus and Crete, ca. 2000-500 B. C.", Nicosia: 87-100.

Muhly, J. D. (1986), The Role of Cyprus in the Economy of the Eastern Mediterranean, in: V. Karageorghis (ed.), Acts of the International Archaeological Symposium "Cyprus between the Orient and the Occident", Nicosia: 45-62.

Nikolaou, K. (1979), Minoan Survivals in Geometric and Archaic Cyprus, in: V. Karageorghis (ed.), Acts of the International Archaeological Symposium "The Relations between Cyprus and Crete, ca. 2000-500 B.C.", Nicosia: 249-256.

Nikolaou, K. (1980-1981), Archaeology in Cyprus 1978-80, Archaeological Reports 27: 56.

Papadopoulos, T. J., Kontroli-Papadopoulos, L. (1992), Aegean Cult Symbols in Cyprus, in: P. Åström (ed.), Acta Cypria: Acts of an International Congress on Cypriote Archaeology Held in Göterborg on 22-24 August 1991, Jonsered: 330-359.

Pecorella, P. E. (1977), Le tombe dell' età del bronzo tardo della necropoli a mare di Ayia Irini "Paleokastro", Roma.

Podbielski, Z. (1989), Stownik roślin użytkowych, Warszawa.

Poursat, J.-C., Loubet, M. (2005), Métallurgie et contacts extérieurs à Malia (Crète) au minoen moyen II: Remarques sur une série d'analyses isotopiques du plomb, in: R. Laffineur, E. Greco, (eds.), EMPORIA: Aegeans in the Central and Eastern Mediterranean, (Aegaeum 25), Liège-Austin: $117-121$.

Pulak, C. (2001), The Cargo of the Uluburun Ship and Evidence for Trade with the Aegean and Beyond, in: L. Bonfante, V. Karageorghis (eds.), Italy and Cyprus in Antiquity: 1500-450 B. C., Nicosia: $13-60$.

Powell, B. B. (2002), Seals and Writing in the Ancient Near East and Cyprus, in: J. S. Smith (ed.), Script and Seal Use on Cyprus in the Bronze and Iron Ages, Boston: 227-248.

Rehak, P., Younger, J. G. (2001), Neopalatial, Final Palatial, and Postpalatial Crete, in: T. Cullen (ed.), Aegean Prehistory: A Review, Boston: 383-465.

Shaw, J. W. (1995), Two Three-Holed Stone Anchors from Kommos, Crete: Their Context, Type and Origin, International Journal of Nautical Archaeology 24: 279-291. 
Shaw, J. W. (1998), Kommos in Southern Crete: An Aegean Barometer for East-West Interconnections, in: V. Karageorghis, N. Stampolidis (eds.), Eastern Mediterranean: Cyprus-Dodecanese-Crete 16th-6th Cent. B. C., Athens: 13-27.

Shaw, J. W. (2004), Kommos: The Sea-Gate to Southern Crete, in: L. P. Day, M. S. Mook, J. D. Muhly (eds.), Crete beyond the Palaces: Proceedings of the Crete 2000 Conference, Philadelphia: 43-52.

Smith, J. S. (2002), Problems and Prospects in the Study of Script and Seal Use on Cyprus in the Bronze and Iron Ages, in: J. S. Smith (ed.), Script and Seal Use on Cyprus in the Bronze and Iron Ages, Boston: $1-47$.

Sørensen, A. H. (2008), The Cypriot Connection: Aspects of Cretan Contacts with Cyprus during the MB-LB I Periods, in: A. McCarthy (ed.), Island Dialogues: Proceedings of the Postgraduate Cypriot Conference (POCA) 2006, Edinburgh: 154-183.

Steel, L. (2004), Cyprus before History: From the Earliest Settlers to the End of the Bronze Age, London.

Stos-Gale, Z. A. et al. (1997), Lead Isotope Characteristic of the Cyprus Cooper ore Deposits Applied to Provenance Studies of Copper Oxhide Ingots, Archeometry 39: 83-123.

Stos-Gale, Z. A., Gale, N. H. (1990), The Role of Thera in the Bronze Age Trade in Metals, in: D. A. Hardy et al. (eds.), Thera and the Aegean World III, London: 72-92.

Stos-Gale, Z. A., Macdonald, C. F. (1991), Sources of Metals and Trade in the Bronze Age Aegean, in: N. H. Gale (ed.), Bronze Age Trade in the Mediterranean, Jonsered: 249-288.

Tatton-Brown, V. (1997), Ancient Cyprus, London.

Tsipopoulou, M. (1997), Phasti-Droggara: un dépôt de céramique de la fin de l'Âge du Bronze et le début de l'Âge du Fer provenant de Créte orientale, in: J. Driessen, A. Farnoux (eds.), La Crète mycénienne: Actes de la Table Ronde Internationale organisée par l'École française d'Athènes (26-28 Mars 1991), Paris: 455-484.

Vermeule, E. T. (1974), Toumba tou Skourou: The Mound of Darkness, Boston.

Vermeule, E. T. (1976), Toumba tou Skourou, Northwest Cyprus, AJA 80: 78.

Vincitelli, I. (1976), Alasia: per una storia di Cipro nell'età del bronzo, Rome.

Warren, P., Hankey, V. (1989), Aegean Bronze Age Chronology, Bedminster.

Watrous, L. V. (2001), Crete from Earliest Prehistory through the Protopalatial Period, in: T. Cullen (ed.), Aegean Prehistory: A Review, Boston: 157-224.

Webb, J. M. (1999), Ritual Architecture, Iconography and Practice in the Late Cypriot Bronze Age, Jonsered.

Webb, J. M., Frankel, D. (1999), Characterizing Philia Facies: Material Culture, Chronology, and the Origin of the Bronze Age in Cyprus, AJA 103: 3-43.

Yon, M. (1970), Sur une représentation figurée chypriote, $B C H$ 94: 311-317.

Yon, M. (1971), Salamine de Chypre II. La tombe T. I. du XI ${ }^{e}$ s. av. J.-C., Paris.

Yon, M. (1979), Chypre et la Crète au XI e s., in: V. Karageorghis (ed.), Acts of the International Archaeological Symposium "The Relations between Cyprus and Crete, ca. 2000-500 B. C.", Nicosia: 241-248.

Zeman-Wiśniewska, K. (2012), Of 'Goddesses' and 'Warriors'. Gender Aspects of the Cypriot 'Goddesses with Upraised Arms", in: A. Georgiou (ed.), Cyprus an Island Culture: Society and Social Relations from the Bronze Age to the Venetian Period, Oxford: 153-160. 